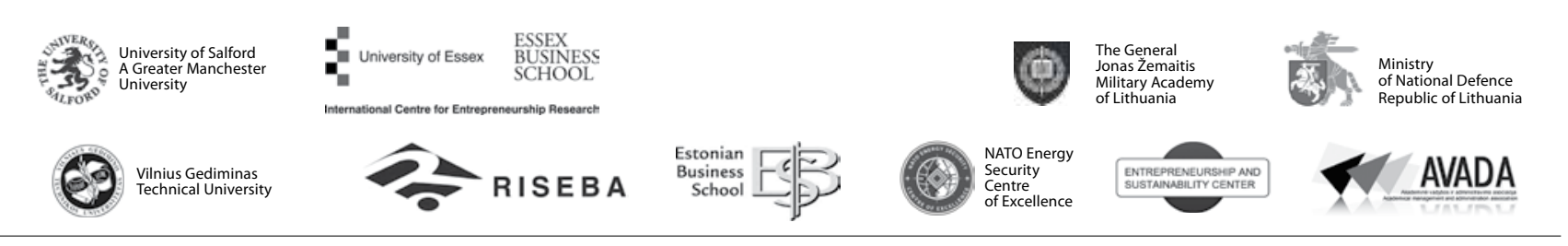

\author{
JOURNAL OF SECURITY AND SUSTAINABILITY ISSUES \\ ISSN 2029-7017 print/ISSN 2029-7025 online \\ 2017 December Volume 7 Number 2 \\ http://doi.org/10.9770/jssi.2017.7.2(5)
}

\title{
ENSURING PUBLIC SECURITY IN THE FIELD OF TRAFFIC SAFETY
}

\author{
Vladas Tumalavičius ${ }^{1}$, Alvydas Šakočius ${ }^{2}$ \\ ${ }^{1,2}$ The General Jonas Žemaitis Military Academy of Lithuania, Šilo Str. 5A, Vilnius LT-10322, Lithuania \\ E-mails: ${ }^{1}$ vladas.tumalavicius@gmail.com; ${ }^{2}$ alvydas.sakocius@lka.lt
}

Received 15 February 2017; accepted 20 September 2017

\begin{abstract}
The article presents the current issues and latest trends of the legal and administrative aspects of ensuring public security in the field of how road traffic safety is ensured. The legal regulation in this area and the problems of organizing the activity of institutions responsible for traffic safety are discussed; the situation of traffic safety in Lithuania and other countries in the Baltic region is studied. Utmost attention is attached to the organization and coordination of comprehensive measures, dedicated to the reduction of the rate of accidents. The authors applied general scientific methods of studying objective reality, peculiar to legal sciences: systematic document analysis, meta-analysis, structural-functional analysis, teleological, comparative, critical approach, generalisation and prediction. As a result in this research is emphasised the importance of decentralisation in ensuring public security at the level of the road traffic safety; the main guidelines of modernization in this field are presented.
\end{abstract}

Keywords: public security, road traffic safety, deviant behavior on roads, traffic accidents, optimization, modernization.

Reference to this paper should be made as follows: Tumalavičius, V.; Šakočius, A. 2017. Ensuring Public Security in the Field of Traffic Safety, Journal of Security and Sustainability Issues 7(2): 233-246. DOI: http://doi.org/10.9770/jssi.2017.7.2(5)

JEL Classifications: K1, K14, F52

\section{Introduction}

Transport today has become one of the key factors in the development of different branches of the economy; the moving force of national economies; and the guarantee of economic stability (Jaržemskis et al. 2012; Beifert 2016; Otter et al. 2017). Basing on the residents' survey data of the last decade, a traffic safety problem has been indicated among the four most significant challenges of public security in the country. In 2014, 3325 traffic accidents were recorded in Lithuania, having resulted in 265 deaths and 3889 injured people (Vileikienè 2015). By Eurostat data, comparing the indicators of Lithuania and other EU countries, it is evident that the situation in our country remains one of the worst: in 2014 by the number of traffic fatalities only Latvia was ahead of Lithuania, the similar situation was in Romania and Bulgaria (Vileikiene 2015). All this witnesses the necessity to search for new comprehensive ways for situation improvement on the road.

There are various threats which affect security of sustainable regional development (Beifert 2016; Grubicka, Matuska 2015; Limba et al. 2017; Prause 2016; Štitilis et al. 2016; Lankauskienė, Tvaronavičienè 2012; Teivāns-Treinovskis, Jefimovs 2012; Tumalavičius et al. 2016; Tumalavičius 2016; Tumalavičius, Greičius 2017; Tvaronavičienė 2016; Zahars, Stivrenieks 2015, Kordík, Kurilovská 2017).

The concept of public security as a general scientific and law category was explored deeper by Fukuda-Parr and Messineo (2011, 2012); Kupruvesas and Sargevičius (2007); Matulionytė (2008). Aleksonis and Aleksonytė 
(2012); Janušauskas et. al (2012); Kalašnykas and Deviatnikovaitè (2007) researched the activity of international and European Union institutions in this area.

Certain aspects of ensuring traffic safety were studied by Daukšaitè (2014), Jost et al. (2012), Tumas and Čigrin (2010). Even though the above-mentioned and other authors are involved in exploring the individual aspects of ensuring public security, making use of the further discussed scientific methods and processing the most important scientific insights using them, an analysis is provided of the problems of coordination and modernization in ensuring public security.

Each member of the society may be treated as a traffic participant, this predetermines the general interest in traffic safety. For example, in the Program of the Government for 2012-2016, ensuring traffic safety in the country is indicated as a priority task. Traffic safety is closely linked with a traffic accident since ensuring traffic safety is deemed to be the activity "whereby it is aimed to prevent road traffic accidents and to facilitate their consequences” (Daukšaitė 2014).

It is noteworthy that traffic safety enforcement is important not only on roads but also everywhere where traffic is possible (for example, in the air and water). Since traffic is most intensive and accident rate is highest on roads, the problems of road traffic safety are most frequently analyzed in the scholarly literature.

In Lithuania where the transport system has been changing rapidly, the dynamic growth of the number of automobiles and variation in the need of transit transportation is fixed, simultaneously with the traffic intensity the probability of accident rate increases (Dainauskas, Brazukienè 2013).

The complex factors affecting traffic safety are: behavior of traffic participants, technical condition of vehicles and roads, and the environment - lighting, meteorological conditions (Daukšaite 2014). According to Dainauskas and Brazukiene (2013), the four factors of traffic accidents have been traditionally distinguished: human factor, vehicle, road, and the surrounding environment. Some authors additionally single out the fifth factorsociety per se. Nevertheless, the human factor most often is fatal: "a human being is the worst acting link in the system "traffic participant-vehicle-road"; that is, most of road accidents are caused by human actions" (Dainauskas, Brazukienè 2013). This has also been evidenced by statistical data proving thereof that the major part of traffic accidents resulting in human victims were due to the fault of drivers. For example, in 2005 drivers caused 74.1 percent of traffic accidents and in $2014-64.3$ percent (pedestrians, correspondingly, 17.3 percent and 8 percent) (Vileikienè 2015).

The crash rate is to be associated with the culture of society: the way of life of social groups, traditions, family life and work models, etc. It is from here that the concept of driving culture pertaining to road traffic culture in society has been derived. Some sociologists, for example, as the axis of causality of the high accident rate in Lithuania see the concept of aggressive society, which "predicts the aggressive behavior on the roads and is relevant to the crisis of values, poverty, economic and social inequality" (Dainauskas, Brazukienè 2013). Due to this reason, the deviant behavior on the roads, like crime in general, is not being curbed by legal measures alone. On the contrary, the traffic safety situation may be influenced by "a variety of legal, administrative, engineering, and educational measures and scientific research works. An impact of all these constituent parts on safe traffic is equally important and depends directly on the country's economy, state-allocated funds, residents' culture, their understanding of safe traffic, and approach of the state and public institutions in tackling traffic safety issues" (Tumas, Čigrin 2010). 


\section{Contemporary legal regulatory system of traffic safety}

After the State re-established its independence, utmost attention was devoted to one of the elements of the traffic safety system - the roads. In addition, ensuring road traffic safety in essence is regulated by the statutory implementing legal acts. As noted by Greičius and Vitkauskas (2002), "sub-statutory executive legal acts, adopted by the Government, not being able to grant enough legitimacy to its actions, constricted the possibilities for implementing legal norms and did not cover the legal regulation of all constituent parts of the traffic system and therefore have not shaped the sufficient legal framework, on the basis thereof the issues of safe traffic in all preventive work trends could be comprehensively tackled." The situation got changed after 2000 when the laws regulating separate parts of the traffic system have been adopted. Nevertheless, a conclusion is to be drawn that the first decade of the independence when necessary legal and other measures have not been undertaken for tackling human factor issues in the field of traffic safety prejudiced the further solution of problems related to driving culture.

Legal basis for enforcement traffic safety. Directive 2015/413/EU is to be mentioned at EU level whereby more favorable conditions are created for a cross-border exchange of information on road-safety related traffic offences. This Directive is aimed at improving road traffic safety in the EU and ensuring the application of sanctions for road traffic offences committed in another Member State. The Directive applies to the following traffic offences: speeding, driving while under the influence of psychoactive substances, failing to follow road signs, etc. It is important to mention that under this Directive the competent authorities of the Member States, investigating the cases of the Road Traffic Rules offences, will have the opportunity to obtain the data about the vehicle owner or holder, registered in another Member State, by conducting automated searches in the databases of vehicles of other Member States.

In the Law on the Basics of the National Security (1997) road safety is referred to as one of the public security policy priorities; it is also stated that state institutions must take efficient measures for safeguarding road traffic safety and guarantee funding for the implementation of these measures, creation of the necessary legal basis, organization and coordination of the activities of state institutions and private persons and complex measures, intended for reduction of accident rate. It is regulated in Article 4 of the Republic of Lithuania Law on the Principles of the Activities of Transport (1991) that public administration of transport is conducted by the Government, the Ministry of Transport and Communications, and municipal institutions. The Ministry of Transport and Communications shall form a transport policy of the State, organize and coordinate its implementation, organize the drafting of programs for strategic transport systems, inter alia traffic safety development. Article 10 of the Law regulates that safe transport traffic is ensured in accordance with technical, technological, social, and organization requirements which are intended for transport infrastructure, vehicles, and traffic participants. Hence, the trinary traffic safety system, consisting of three links - transport infrastructure, motor vehicles, and traffic participants - is embedded in the Law. Special legal acts, safeguarding of traffic safety, may be devoted to each of these links. In the Republic of Lithuania Law on Roads (2000) safeguarding of safe traffic is perceived as transport infrastructure - in Article 19 Part 2 it is stipulated that safe traffic measures shall be implemented when designing, building, reconstructing, repairing and maintaining roads in compliance with the normative documents pertaining to the designing of Lithuanian roads, standards of the Republic of Lithuania, and other normative technical construction documents. However, most exhaustively safeguarding of safe traffic is regulated in the special law, the Law on Road Traffic Safety (2000). Article 1 of this Law establishes the legal basis of road traffic safety in the Republic of Lithuania, obligations of the state and municipal institutions and agencies in implementing the policy of road safety, training of traffic participants, and the principal rights and obligations of traffic participants, persons, responsible for road supervision, police, customs and other controlling inspectors, and also other requirements linked with the technical condition of motor vehicles, checking of the technical condition and registration of motor vehicles, traffic safety requirements set for roads in striving to protect the lives, health and property of traffic participants and other persons and improve the traffic conditions of transport and pedestrian traffic. Article 4 regulates the principles of traffic safety enforcement.

The first principle covers the duty of the state to create safe and equal conditions for all traffic participants to 
participate in traffic; the duty of traffic participants is to be aware of and comply with the traffic established by the state.

The second principle - enforcement of health and life safety of traffic participants is more important than the economic results of economic activity.

The third principle encompasses assessment of private, public, and state interests and their coordination in safe traffic enforcement.

Nonetheless, not denying the importance of the above provisions, their wording, especially of the first one, expressing more general duties of the state and traffic participants rather than the principle of safety enforcement are subject to criticism. Article 6 of the Law regulates that traffic safety shall be enforced by complex measures:

- specifying the powers of the Government, its authorized institutions, and municipalities in the field of traffic safety enforcement;

- regulating and controlling activities of legal and natural persons in the field of traffic safety enforcement; adopting legal acts regulating traffic safety enforcement;

- educating and training traffic participants and professionals; resolving issues related to instillation of new science and technology developments in transport field;

- ensuring, materially and financially, implementation of traffic safety measures;

- implementing socially oriented policy of compulsory insurance against civil liability in the field of transport;

- carrying out state supervision and control of the implementation of legal acts regulating traffic safety enforcement;

- promoting of purchase and use of safe and environmentally friendly vehicles.

However, it is noteworthy that this Law regulates only the basic guidelines for enforcement of traffic safety; even though specific safety measures have not been regulated - this is left to the statutory implementing legal acts.

The most important statutory implementing legal act in the field of traffic enforcement indisputably is the Road Traffic Rules (2002) (further the RTR). The RTR enforces not only the specific rules that traffic participants must follow in order to safeguard road traffic safety but also the duty of traffic participants of general type to base their behavior on mutual respect and caution (p. 50). It is regulated in p. 53 that traffic participants must comply with all the necessary precautionary measures, not to endanger other road users, other persons or their property and the environment, not to interfere traffic, damage the road, traffic regulation measures, emergency communication lines and plantations. In order to avoid damaging effects or to reduce them, traffic participants must take all the necessary measures, except in cases where this would result in a risk to their own life or health as well as other people, or when such measures would cause more harm compared to that which could be avoided (p. 54).

Resolution of the Government of 13 April 2005 "On the Approval of the Rules for Control of Technical Condition of Vehicles on the Roads of the Republic of Lithuania" is of importance for safeguarding of road traffic. These rules are designed to ensure safety of vehicles and organizing of their control on the road. Some more narrow aspects of road traffic safety enforcement are regulated by the Lithuanian Police Commissioner General orders (2015). Attention shall be focused on the fact that road traffic safety is regulated by numerous implementing acts; therefore, some doubt exists as to their systematic approach and compatibility.

Liability for violations of the Road Traffic Rules. The laws of the Republic of Lithuania envisage both penal and administrative liability for the RTR violations. Penal liability for violation of the RTR is foreseen in Article 281 of the Criminal Code of the Republic of Lithuania (2000) (further the CC) and covers the liability for the RTR violation if this resulted in an accident causing a non-severe impairment to another person's health; for the RTR violation committed under the influence of psychoactive substances, if this resulted in an accident causing a non-severe impairment to another person's health or the victim suffers major property damage; for RTR 
violations where this resulted in an accident causing a severe impairment to another person's health, separately foreseeing the stricter liability for violations under the influence of intoxication; for RTR violations where this resulted in an accident causing a person's death (also foreseeing the stricter liability for violations under the influence of intoxication).

It should be emphasized that it is planned to amend and supplement the Article with a new Part 7 whereby enforcing that a person shall be held liable if driving a vehicle or training practical driving under the influence of alcohol his blood contained more than 1.5 promilles of alcohol. Meanwhile, the liability for the remaining RTR violations is foreseen in the Code of Administrative Violations of Law of the Republic of Lithuania (1985) (further CAVL). CAVL Article 126 whereby driving of motor vehicles under the influence of intoxication is foreseen the strictness of sanction is differentiated by a degree of intoxication. In addition, Article $130^{2}$ envisages the stricter liability for repeated driving when the drivers are inebriate, including the confiscation of the vehicle. According to the foreseen amendments to the Criminal Code of the Republic of Lithuania, the newly adopted Code of Administrative Offences of the Republic of Lithuania (2015) (further the CAO) contains amendments to the liability for driving when the drivers are inebriate, foreseeing that the administrative liability is imposed for driving a vehicle while lightly or moderately intoxicated with alcohol. The new CAO provides the liability for driving with more than 0 but less than 0.4 promille of alcohol for novice drivers as well as drivers of taxi automobiles, mopeds, motorcycles, tricycles, light quadricycles, quadricycles, heavy quadricycles, vehicles with the maximum permissible weight higher than $3.5 \mathrm{t}$ or with more than 9 seats, and vehicles carrying dangerous goods. Hence, the tendencies of the stricter liability for the RTR violations prevail in the present legal regulation.

In this context, one of the recent rulings of the Lithuanian Supreme Court (further the LSC) should be mentioned. It predetermined one of the most important turning-points of precedent law in the field of criminal liability for RTR violations. The LSC acknowledged in this ruling that a driver who escaping from the police chase completely ignored the RTR, committed a gross violation of the rules, at intensive traffic, being intoxicated with alcohol (2.02 promilles) was driving at a speed thrice exceeding the maximum permissible speed; did not pay any attention to road signs and the prohibiting red signal of the traffic-lights, while other traffic participants, having the right of pre-emption to drive through intersections, had no opportunity to behave in such a way that irrespective of the behavior of the convict could avoid a traffic accident, acted with indirect intent but not negligently. In this case the driver whose dangerous actions resulted in a traffic accident and death of people was convicted not according to Article 281 Part 6 of the Criminal Code where the driver is liable for a traffic accident committed while being inebriate with alcohol during which a person died (a person is held liable according to this Article only in the case of fault due to negligence), but according to CC Article 129 Part 2, p. 5 (premeditated murder of two or more people) (Criminal case No. 2K-P-498-746/2015). Such decision of the Lithuanian Supreme Court was discussed intensively at the legal community.

It is assumptive that adoption of such ruling was conditioned not so much by the actual circumstances or legal argumentation but also by the increased interest in the press in the criminal offences committed under intoxication and intolerance to them in the society. Without more detailed analysis of the plot of an accident, it should be said that in the above situation the court could have justified simply enough that in the said situation it was the fault due to negligence. The Court of Appeal, actually, has chosen such a model of decision too. The choice by the LSC, however, to change its practice in essence shows the sufficiently resolute self-determination and goal to tighten the penal policy in this field.

Expansion of criminal liability. The aim to foresee the penal liability for driving being intoxicated with alcohol or under the influence of psychoactive substances is to be discussed more broadly, expecting that drivers, avoiding the penal liability and conviction, will be deterred from commission of such RTR offences. Experience of other states is also used as a basis in initiating such changes.

For example, Article 262 Part 2 of the Latvian Criminal Code provides for the penal liability for driving or training practical driving if a person does not have a driving license, and if a person is intoxicated with psycho- 
active substances. Article 178a Part 1 of the Criminal Code of Poland also envisages the liability for driving a vehicle being inebriate. The analogous penal liability is foreseen in Article $316 \mathrm{Pt} 1$ of the German Criminal Code (Daukšaite 2014). It should be noted that penal liability for driving being inebriate was also foreseen in Article 281 Part 6 of the Criminal Code of the Republic of Lithuania (wording of 26 September 2000), but doubting whether the dangerousness of offence is actually enough for initiating the penal liability, criminalization of this offence was cancelled in 2003. Today also the compatibility of criminalization of driving while intoxicated with the principle ultima ratio is subject to discussion, as well as an issue whether it concerns any intoxication or the grave intoxication. As claimed by Daukšaite (2014), "the violations of mechanisms created for protecting socially acknowledged values (breach of the set order) shall be treated as impermissible or illegal acts, and the violations of the values themselves as criminal acts." On the basis thereof, it is possible to identify whether the dangerousness of an act is sufficient for it being criminalized.

Nevertheless, it is assumptive that this formula does not ultimately resolve the dilemma of the expediency of criminalization of driving under the influence of intoxication. While tackling an issue of criminalization of driving under intoxication, account shall be taken of the general situation.

Firstly, administrative penalties, applied for driving being inebriate, - large penalties and loss of the right to drive - deter and suspend persons from commission of offences in the future.

Secondly, cases of administrative violations of law are investigated and examined more efficiently; therefore, after initiating the case of administrative violation of law rather than the criminal case, both time and human and financial resources are saved.

Thirdly, expansion of penal liability contributes to the creation of "criminal society" where a criminal act itself becomes greatly devalued (Daukšaitè 2014).

Fourthly, account should be taken of the fact that such expansion of penal liability would not comply with the aim to change the penal policy, given that the number of imprisoned convicts is almost twice higher than the average in the EU: such effects would arise not only upon foreseeing in a sanction the opportunity to impose a penalty of imprisonment but also upon not foreseeing it since conviction acquired that way may become an obstacle in staying execution of penalty after commission of another criminal act in the future (Daukšaite 2014).

Hence, a conclusion is to be drawn that a decision to criminalize driving under the influence of intoxication with psychoactive substances is subject to criticism and will not yield long-term positive results. It is assumptive that more efficient would be various administrative impact measures, for example, the obligation to participate in the driver rehabilitation programs, to take part in the courses on the damage caused by psychoactive substances, etc.

Thus, it should be said that transport today is the main factor in the development of various branches of the economy and the moving force of national economies and a guarantee of economic stability. The four factors of traffic accidents have been traditionally distinguished: human factor, vehicle, road, and the surrounding environment. Most of road accidents as a result of which people suffered were due to the fault of drivers; therefore, utmost attention is to be devoted to a human factor. The deviant behavior on roads, like crime in general, is not being curbed by legal measures alone - for safeguarding traffic safety it is necessary to apply complex measures. The first decade of the independence, when attention was focused on road infrastructure improvement and no necessary legal and other measures were undertaken for tackling human factor problems in the field of traffic safety, prejudiced the further solution of the problems related to the already formed deviant driving culture.

Road traffic safety is regulated by numerous laws and implementing legal acts; therefore, some doubt arises as to the systematic approach and compatibility thereof. The laws of the Republic of Lithuania envisage both penal and administrative liability for violation of the Road Traffic Rules. The tendencies of the stricter liability for the RTR violations prevail in the present legal regulation. This is witnessed by a resolute turning-point in the 
Lithuanian Supreme Court practice when the commission of a traffic accident by the driver while being inebriate and upon the gross violation of the RTR was qualified as premeditated murder. The amendments adopted to the Criminal Code of the Republic of Lithuania whereby a person is held liable for driving a vehicle under the influence of an average or heavy degree of intoxication are to be evaluated critically as hardly compatible with the principle of ultima ratio, principles of process promptness and efficiency, as well as with an aim of reducing the number of convicted persons in the imprisonment facilities.

\section{Problems of organizing the activities of traffic safety enforcement institutions}

The Law on Road Traffic Safety regulates the institutional framework of traffic safety enforcement. Article 7 of the Law has enforced the Government to formulate the state policy on traffic safety enforcement and approve the National Traffic Safety Program and its plan for implementation measures. The standing State Traffic Safety Commission (hereinafter the Commission) shall control the implementation of the state policy on traffic safety enforcement. This Commission shall submit to the President of the Republic, the Seimas, the Government, other state and municipal institutions and agencies proposals on the implementation of this Law; submit to the state and municipal institutions and agencies conclusions on the compliance of legal acts with traffic safety requirements; draft a project of the National Traffic Safety Program and submit it to the Government; consider issues of traffic safety enforcement and take decisions on them. Article 10 of the Law regulates exhaustively the functions of separate ministries in the fields of traffic safety enforcement.

For example, the functions of the Ministry of Transport and Communications or its authorized institutions in essence shall cover improvement of road infrastructure and ensuring the compliance of vehicles with technical requirements, education of traffic participants, and identification of the driver training procedure.

The Ministry of Social Security and Labor or its authorized institutions shall identify persons entitled to use the distinctive sign "Disabled" and the procedure for issuing disabled persons a parking card and a document certifying the right to use the distinctive sign "Disabled".

The Ministry of Health or its authorized institutions shall set the requirements and procedure for driver health checks, the procedure of training traffic participants to provide medical first aid, determine health problems due to which the right to drive certain categories of motor vehicles is restricted or withdrawn.

A positive evaluation is to be given to the expansion of functions of the Ministry of Education and Science in the new wording of the Law which covers organizing the compulsory basic training of traffic safety at the educational institutions and training of children during which skills of safe bicycle driving are acquired.

The Ministry of the Interior has the comparatively the broad functions: to set conditions and procedure for expertise of motor vehicle drivers; to collect data on driving licenses issued to motor vehicle drivers; to set the procedure for issuing driving licenses of motor vehicle drivers withdrawing and returning the right to drive vehicles, etc.

However, it is subject to discussion whether the functions attributed to the Ministry of the Interior, which as specified in the Law are implemented in coordination with the Ministry of Transport and Communications, in order to avoid the overlapping of functions, could be successfully implemented by the Ministry of Transport and Communications.

Meanwhile, the powers of the Ministry of Agriculture cover the issues of traffic safety related to the traffic of tractors and self-propelled machines, driver training and the procedure of technical inspection.

Certain functions are also delegated to the director of the municipal administration and the latter shall:

- approve the traffic safety program of a municipality, form the municipal traffic safety commission from the representatives of the municipal administration bodies and the state administration bodies at the municipal- 
ity, non-governmental organizations, and approve its regulations;

- resolve traffic organization issues in urban and rural areas, on local significance roads;

- implement educational training activities in the field of traffic safety, etc.

In this situation it should be also assessed whether the education functions in the field of traffic safety are to be attributed either to a municipality or the Ministry of Education since according to the present legal regulation these functions are overlapping.

Finally, it should be noted that actually many functions in the field of traffic safety enforcement are performed by specialized police units and authorized police officers. The latter regulate traffic, examine the RTR violations, conduct a pre-trial inquiry in traffic accident cases, write up records of administrative offences in the cases provided for in law, examine cases of administrative offences and take decisions in these cases and impose other measures prescribed by law, etc.

Attention is, however, to be focused on the fact that not all functions are regulated smoothly and precisely; it is possible to maintain that regulation is too meticulous and not specific. For example, the first function indicates that the police supervise how traffic participants adhere to the provisions of this Law and the order of traffic prescribed in other laws. Meanwhile, the fifth function is to control how natural and legal persons carry out responsibilities for traffic safety enforcement provided for in laws and other legal acts. It is evident that such regulation is to be revised by eliminating the excessive provisions from the legal act text. Thus, the text of the law would become more fluent and understandable, the more so that lists of institutional functions are not final.

The activities of the Lithuanian Road Police Service should be discussed separately. The Lithuanian Road Police Service is the specialized police institution, the purpose of which is within the powers granted by the Police Commissioner General together with the Police Department under the Ministry of the Interior to represent the police in the state traffic safety system, to carry out traffic supervision on the roads of the Republic of Lithuania, as well as to perform other special functions delegated by other legal acts at a level of the state and on the non-territorial principle. The activities of the Lithuanian Road Police Service are regulated in detail in the Lithuanian Road Police Service Regulations (Resolution No. 5-V-170 of 26 February 2010). It is regulated in the Regulations that the objectives of the Service activities are to ensure the implementation of effective measures for improving safe traffic on the roads and reducing the number of traffic accident victims; to participate in shaping a police activity strategy in the field of traffic safety and implement it; to coordinate the implementation and control of this strategy. To implement these goals, the Service shall identify priority trends and measures for safe traffic improvement and shall:

- coordinate and control activities of police institutions of the country in the field of traffic safety enforcement;

- organize prevention of traffic accidents and RTR offences; perform traffic supervision and maintain public order on the roads;

- escort and accompany official delegations;

- prevent criminal acts and other offences of law on the roads;

- participate in drafting training programs, etc.

It is noteworthy that the functions attributed to the Road Police Service are numerous and varied, including some that are somewhat unexpected, for example, to control transit of the Russian Federation citizens through the territory of the Republic of Lithuania and illegal migration to the EU; to carry out corruption prevention measures; within its powers to participate in the activities of commissions and workgroups, etc. Upon surveying the functions attributed to the Road Police Service, their abundance and overlapping with the functions delegated to other institutions strike the eye. For example, it hardly belongs to the function of the Road Police Service to identify priority trends and measures for safe traffic improvement since safe traffic programs and strategies are drafted by the Government. Certainly, the Road Police Service may take part in preparing such programs and consult the representatives of the Government although it may be hardly considered to be an independent function of this institution. 
Another example - control of transit of the Russian Federation citizens and illegal migration to the EU; it is not clear why this function is attributed to the Road Police Service if the State Border Guard Service is responsible for it in any case. Not understandable still more is why the Russian Federation is exactly distinguished, not, for instance, control of transit of the citizens of the Republic of Belarus through the Republic of Lithuania.

Some not fully specified functions are also delegated to the Road Police Service, for example, to perform corruption prevention functions, and it is not clear whether the Road Police Service is deemed to be the institution responsible for corruption prevention per se (e.g., like the SIS), or it is just obligated to perform corruption prevention measures inside the institution (which is obligatory for any institution). Therefore, such and similar functions shall be elaborated, for example, indicating that the Road Police Service is responsible for corruption prevention and control in respect of the road police officers (e.g., installation of video recorders in the official automobiles, etc.).

Regulation of the functions that are common to many institutions should be also rejected, for example, the above-mentioned function "to participate in the activities of commissions and workgroups" since inclusion of such functions aggravates the text of the legal act and is not expedient.

In addition, due to such detailed regulation of the Road Police Service activities and the delegated functions thereof in the Regulations, a list of functions attributed to the Lithuanian Road Police Service at the law level is unreasonably extended. Actually, the same may be stated of the regulations of other institutions responsible for safe traffic enforcement (Order No. 3-179 of 9 March 2012).

Thus, it should be said that the Law on Road Traffic Safety regulates the traffic safety enforcement institutional framework and discloses exhaustively the functions of each institution. It is seen from the survey of the Law that with account taken of the necessity to safeguard traffic safety these functions are delegated to different ministries and their authorized institutions. Nevertheless, even in the Law the overlapping of the functions of the institutions was not fully avoided, for example, the functions delegated to the Ministry of the Interior actually are similar to those attributed to the Ministry of Transport and Communications, certain functions delegated to the municipal administration also coincide with the functions delegated to the state institutions.

Moreover, certain functions actually are identical, only presented in a different way; therefore, such regulation should be revised by eliminating the excessive provisions from the legal act text. Thus, the text of the law would become more fluent and understandable, the more so that lists of institutional functions are not final. Upon surveying the functions attributed to the Road Police Service, their abundance and overlapping with the functions delegated to other institutions strike the eye. It is also necessary to revise some unclearly defined and too abstractly formulated functions. Regulation of the functions that are common to many institutions should be also rejected; therefore, their regulation is not expedient at all.

Finally, due to such detailed regulation of institutional activities in the Regulations and the delegated functions thereof, a list of functions attributed to the specific institution at the law level is unreasonably extended.

\section{The system for implementing complex measures for accident rate reduction}

As stated by S. Greičius and K. Vitkauskas (2002), "safe traffic on the roads is affected by a lot of components which may be concentrated into the closely interlinked totality, revealing three key elements: roads, vehicles, and traffic participants. All the preventive work for ensuring safe traffic shall be focused on improving the functioning of this system." According to the authors, the most important role in this field belongs to the executive authority, which is involved in shaping and improving the required laws, storing up material resources, etc. The literature most often distinguishes three trends in traffic safety enforcement: restructuring of the traffic environment, vehicle technical maintenance and education of traffic participants. As already mentioned, the fourth factor, that is, the road environment, is distinguished in the recent literature, and it is of no less importance for traffic safety (Tumas, Čigrin 2010). V. Tumas and V. Čigrin also mention an interesting factor that safe 
traffic on the road is also impacted by the totality of psychological factors in the country.

Here mention should be made of the Big Five model explaining "constant emotional, interpersonal, experiential, and motivational constructs which describe human behavior in different situations" (Tumas, Čigrin 2010) and distinguishing "the big five personality traits - extraversion, neuroticism, conscientiousness, agreeableness, and openness to experience" (Tumas, Čigrin 2010). Therefore, the question arises how to properly choose, organize, and coordinate complex measures intended for reducing an accident rate in order with their help to achieve the desirable effect.

The main legal act, where the complex measures for accident rate reduction are discussed, is the National Road Safety Development Program for 2011-2017, adopted in 2011. This program has set, probably, a too ambitious goal - to facilitate the implementation of the road safety vision so that no road users are killed or suffer serious injuries in Lithuania.

It is assumptive that such formulation is not quite reasonable since it is evident that such goal is impossible to be achieved. Further, one more objective is to achieve that Lithuania is listed among the ten European Union Member States with the best results in terms of the road users killed in traffic accidents per million of the country's inhabitants (or no more than 60 people killed in traffic accidents per million of inhabitants) by improving the situation in road safety. Further in the program, the priorities are set in accordance with which the objective is to be attained.

The said priorities shall be:

- safe conduct of road users;

- safe roads;

- safe vehicles;

- speedy and qualified first aid to road users;

- modern information technologies.

To implement the first priority, the importance of education in the field of road safety is emphasized. It is also underlined in the program that about 90 percent of traffic accidents are determined by the conduct of road users and their conduct is greatly affected by education and control. It is noted that of importance is to organize children's road safety training, seeking to form traffic safety skills to children; to improve initial training organization processes for drivers since 15 percent of all traffic accidents occur due to the fault of novice drivers; and to improve the knowledge of road safety specialists as the operational benefit in all areas of road safety depends on them.

It is notable that a rather modern and expedient method of regulation has been selected in the program when each set goal is reasonably justified. On the other hand, too abstract tasks, the successful implementation thereof is impossible to be measured, however, are not avoided.

For example, alongside the sufficiently specific tasks, such as how to prepare road safety specialists, teachers and to upgrade their qualification, to develop children's road safety culture abilities at educational establishments, the too abstract tasks, for instance, "to educate the society" are formulated. Such formulations should be avoided since setting of such nonspecific tasks is of no importance; it is a matter of course that the society should be educated on the issues of road safety although it is not clear how to do this.

Further in the program the importance of control of road users is emphasized. It is underlined that control of road users is insufficient on the regional and national roads. Even though a sufficiently concrete problem is put forward, the formulated tasks are comparatively abstract. For example, the first task is "to organize control of road users;" the second task is to exercise "control of dangerous and bully behavior;" the third task is "to exercise control of inebriated road users," etc. 
Evidently, distinguishing of such tasks is not logical since:

- firstly, distinguishing of organization of control of road users as a separate task is not expedient since these tasks fully coincide with the set goal;

- secondly, other set tasks are constituent parts of this task.

Similar problems are also to be distinguished when speaking about the implementation of other priorities, in some cases even tasks are formulated more abstractly than goals. For example, seeking to achieve Priority 3 , a goal is set to increase vehicle safety. Meanwhile, one of the tasks used to implement this goal is to increase the number of safer vehicles. These discrepancies give rise to an impression that program drafters coordinated the program structure not very accurately; therefore, it is evident that seeking for the proper complex accident-rate reduction measures, these shortcomings should be corrected when drafting a new program in 2017.

However, it is noteworthy that even though modern information technologies (should be - their application in ensuring traffic safety) are distinguished in the program as one of the priorities, their application in the program has not been overmuch emphasized.

It is also assumptive that certain measures ensuring road safety enhancement, not mentioned in the present program, should be necessarily included in a new program, for example, driver rehabilitation programs, the importance thereof is underlined at EU level (Conference of European Directors of Roads, 2006). Statistical data submitted in the new program should be also more abundant as it has been made in the Public Security Program.

Study of statistical data should help to distinguish the most important accident reduction measures which should be given more attention. The program should also include examples of the successful experience of other countries in the field of reduction of accident rate on the roads (Jost et al. 2012). The new program should enforce such tasks the implementation thereof would be specifically assessed, also by regulating how the program implementation monitoring would be conducted.

It is assumptive that only in such a case it would be possible to attain the most significant results in improving road safety in the country.

In summary, it should be said that the basic legal act wherein the complex measures for reduction of accident rate are discussed is the National Road Safety Development Program for 2011-2017, adopted in 2011. A quite modern and expedient regulation method has been chosen in the program where each set goal is reasonably justified. On the other hand, in spite of indicating the specific problems, nevertheless, too abstract tasks are inevitable (sometimes even more abstract than the set goals), the successful implementation thereof is impossible to be measured. It is also not always logical to distinguish the tasks when some tasks overlap other ones or even fully coincide with the set goals.

The program does not completely emphasize the application of sophisticated technologies either, even though this is indicated as one of the priorities in the development of safe traffic. In developing a new safe traffic development program in 2017, the shortcomings should be corrected, and therefore it is necessary:

- to include certain measures ensuring traffic safety enhancement not mentioned in the present program (for example, driver rehabilitation programs);

- to submit analysis of more numerous statistical data as well as focusing on the successful experience of other states in this field;

- to ensure that effective monitoring of the program implementation would be possible. 


\section{Conclusions}

Like crime in general, the deviant behavior on roads is not being curbed by legal measures alone - for safeguarding traffic safety it is necessary to apply complex measures.

Road traffic safety is regulated by numerous laws and implementing legal acts; therefore, the reasonable doubt arises as to the systematic approach and compatibility thereof, especially emphasizing that in the statutory implementing legal acts a list of functions attributed to the specific institution at a level of the law is unreasonably extended. The tendencies of the stricter liability for the violations of the Road Traffic Rules prevail in the present legal regulation.

The amendments adopted to the Criminal Code of the Republic of Lithuania whereby a person is held liable for driving a vehicle under the influence of an average or heavy degree of intoxication are to be evaluated critically as hardly compatible with the principle of ultima ratio, principles of process promptness and efficiency, as well as with an aim of reducing the number of convicted persons in the imprisonment facilities.

\section{References}

Aleksonis, G.; Aleksonyte, Ž. 2012. Europos Sąungos institucijų bendradarbiavimas visuomenès saugumo srityje [The European Union Institutional Cooperation in the Field of Public Safety]. Public security and public order 8

Beifert, A. 2016. Regional airports' potential as a driving force for economic and entrepreneurship development - case study from Baltic Sea region, Entrepreneurship and Sustainability Issues 3(3): 228-243. DOI: https://doi.org/10.9770/jesi.2016.3.3(2)

Dainauskas, S.; Brazukienė, I. Lietuvos automobilių kelių avaringumo teritorinė analizė [The Territorial Analysis of Automobile Crashes in Lithuania]. Geography. 2013, 49(1).

Daukšaitè, I. Kelių transporto priemonių vairavimas esant vairuotojams neblaiviems: ar reikalinga plèsti baudžiamosios atsakomybės ribas? [Driving a Road Vehicle under the Influence of Alcohol: Is it Necessary to Expand the Scope of Criminal Liability?]. Legal problems. 2014, 4(86).

Direktyva 2015/413/ES [Directive 2015/413/EU]. Available in Internet: www.policija.lt/index.php?id=22826

Fukuda-Parr, S.; Messineo, C. 2011. Human Security. The New School, New York.

Fukuda-Parr, S.; Messineo, C. 2012. Human Security: A Critical Review of the Literature.

Greičius, S.; Vitkauskas, K. Kelių policijos vykdomo prevencinio darbo poveikis eismo saugumui [Impact of Police Officers' Preventive Work on Ensuring Safe Traffic]. Jurisprudence. 2002, 35(27).

Grubicka, J.; Matuska, E. 2015. Sustainable entrepreneurship in conditions of UN (Safety) and technological convergence, Entrepreneurship and Sustainability Issues 2(4): 188-197. https://doi.org/10.9770/jesi.2015.2.4(2)

Janušauskas, A.; Aleksonis, G.; Aleksonytè, Ž. 2012. Tarptautinių institucijų pozityvi veikla užtikrinant šalies saugumą [International Institutions of Positive Contributions to the Nation's Security]. Management 1(20).

Jost, G.; Allsop, R.; Steriu, M.; Enculescu, S. 2012. A Challenging Start Towards the EU 2020 Road Safety Target. European Transport Safety Council.

Kalašnykas, R.; Deviatnikovaitė, I. Kai kurių bendrųjų Europos Bendrijos teisės principų taikymo ypatumai administruojant viešaji saugumą [European Community Principles in Administration of Public Security]. Jurisprudence. 2007, 4(94).

Kordík, M.; Kurilovská, L. 2017. Protection of the national financial system from the money laundering and terrorism financing, Entrepreneurship and Sustainability Issues 5(2): http://doi.org/10.9770/jesi.2017.5.2(7)

Kupruvesas, V.; Sargevičius, M. 2007. Teisinès sistemos nuostatų igyvendinimas viešojo saugumo srit.yje [Implementation of the Legal System Rules in the Field of Public Security] 1(91).

Lankauskiené, T.; Tvaronavičienè, M. 2012. Security and sustainable development approaches and dimensions in the globalization context, Journal of Security and Sustainability Issues 1(4): 287-297. http://dx.doi.org/10.9770/jssi.2012.1.4(5) 
Lietuvos Aukščiausiojo Teismo Baudžiamųų bylų skyriaus teisèjų kolegijos $2015 \mathrm{~m}$. gruodžio 22 d. nutartis baudžiamojoje byloje Nr. 2K-P-498-746/2015 [Ruling of the Judicial Board of the Criminal Cases Department of the Lithuanian Supreme Court of 22 December 2015 in the criminal case No. 2K-P-498-746/2015].

Lietuvos kelių policijos tarnyba [The Lithuanian Road Police Service]. Available in Internet: www.lkpt.lt/lt/veikla

Lietuvos policijos generalinio komisaro 2010-02-26 ịsakymas Nr. 5-V-170 „Dèl Lietuvos policijos generalinio komisaro 2010-05-27 įsakymo Nr. 5-V-428 „Dèl Lietuvos kelių policijos tarnybos nuostatų ir struktūros schemos patvirtinimo“ pakeitimo“" [Resolution No. 5-V-170 of 26 February 2010 of the Lithuanian Police Commissioner General "On Amendment of Order No. 5-V-428 of 27 May 2010 of the Lithuanian Police Commissioner General "On the Approval of the Lithuanian Road Police Service Regulations and Structural Scheme"].

Lietuvos policijos generalinio komisaro 2015 m. rugsėjo 24 d. įsakymas Nr. 5-V-851 „Dėl vairuotojo pažymėjimų paėmimo ir perdavimo“, 2015 m. rugsėjo 28 d. ịsakymas Nr. 5-V-858 „Dėl Vidutinio važiavimo greičio nustatymo tvarkos aprašo patvirtinimo“ [Order No. 5-V-794 of 9 September 2015 of the Lithuanian Police Commissioner General "On Withdrawing and Transfer of Driving Licences", Order No. 5-V-858 of 28 September 2015 "On the Approval of the Description of the Procedure for Setting the Average Driving Speed"].

Lietuvos Respublikos administracinių nusižengimų kodekso patvirtinimo, įsigaliojimo ir igyvendinimo tvarkos ịstatymas [Republic of Lithuania Law on the Procedure of Approval, Entry into Force and Implementation of the Code of Administrative Offences]. TAR. 07-10-2015, No. 11216.

Lietuvos Respublikos administracinių teisès pažeidimų kodeksas (aktuali redakcija nuo 2016-01-01) [Republic of Lithuania Code of Administrative Violations of Law (new wording since 01-01-2016]. Official gazette. 1985, No. 1-1.

Lietuvos Respublikos baudžiamasis kodeksas (aktuali redakcija) [Republic of Lithuania Criminal Code (new wording)]. Official gazette. 2000, No. 89-2741.

Lietuvos Respublikos kelių įstatymas [Republic of Lithuania Law on Roads]. Official gazette. 2000, No. 101-4492.

Lietuvos Respublikos nacionalinio saugumo pagrindų įstatymas (suvestinè redakcija nuo 2014-10-29) [Republic of Lithuania Law on the Basics of the National Security (consolidated version since 29-10-2014)]. Official gazette. 1997, No. 2-16.

Lietuvos Respublikos saugaus eismo automobilių keliais įstatymas [Republic of Lithuania Law on Road Traffic Safety]. Official gazette. 2000, No. 92-2883.

Lietuvos Respublikos susisiekimo ministro 2012 m. kovo 9 d. įsakymas Nr. 3-179 „Dèl Lietuvos Respublikos susisiekimo ministro 2006 m. lapkričio 30 d. ịsakymo Nr. 3-457 „Dèl Lietuvos automobilių kelių direkcijos prie Susisiekimo ministerijos nuostatų patvirtinimo" pakeitimo“ [Order No. 3-179 of 9 March 2012 of the Republic of Lithuania Minister of Transport "On Amendment of Order No. 3-457 of 30 November 2006 of the Republic of Lithuania Minister of Transport "On the Approval of the Regulations of the Lithuanian Road Administration at the Ministry of Transport and Communications"].

Lietuvos Respublikos transporto veiklos pagrindų ịstatymas [Republic of Lithuania Law on the Principles of the Activities of Transport]. Official gazette. 1991, No. 30-804.

Lietuvos Respublikos Vyriausybès 2002 m. gruodžio 11 d. nutarimas Nr. 1950 „Dèl Kelių eismo taisyklių patvirtinimo“ [Resolution No. 1950 of the Republic of Lithuania Government of 11 December 2002 "On the Approval of the Road Traffic Rules"]. Official gazette. 2003, No. 7-263.

Lietuvos Respublikos Vyriausybès 2005 m. balandžio 13 d. nutarimas Nr. 403 „Dèl Kelių transporto priemonių techninès būklès kontrolès Lietuvos Respublikos keliuose taisyklių patvirtinimo“ " Resolution No. 403 of the Republic of Lithuania Government of 13 April 2005 "On the Approval of the Rules for Control of Technical Condition of Vehicles on the Roads of the Republic of Lithuania"]. Official gazette. 2005, No. 49-1627.

Lietuvos Respublikos Vyriausybės 2011 m. kovo 2 d. nutarimas Nr. 257 „Dèl Valstybinès saugaus eismo plètros 2011-2017 metų programos patvirtinimo" [Republic of Lithuania Government Resolution No. 257 of 2 March 2011 "On the Approval of the National Road Safety Development Programme for 2011-2017’]. Official gazette. 2011, No. 29-1368.

Limba, T.; Plèta, T.; Agafonov, K.; Damkus, M. 2017. Cyber security management model for critical infrastructure, Entrepreneurship and Sustainability Issues 4(4): 559-573. https://doi.org/10.9770/jesi.2017.4.4(12)

Matulionytė, E. Grèsmių nacionaliniam saugumui nustatymas ir jų prevencijos galimybès [System of National Security, Threats and Prevention Possibilities]. Jurisprudence. 2008, 4(106).

Most Effective Short, Medium and Long-Term Measures to Improve Safety on European Roads. Conference of European Directors of Roads, 2006. 
Otter, C.; Watzl, C.; Schwarz, D.; Priess, P. 2017. Towards sustainable logistics: study of alternative delivery facets, Entrepreneurship and Sustainability Issues 4(4): 460-476. https://doi.org/10.9770/jesi.2017.4.4(5)

Prause, G. 2016. E-Residency: a business platform for Industry 4.0?, Entrepreneurship and Sustainability Issues 3(3): 216-227. https: //doi.org/10.9770/jesi.2016.3.3(1)

Štitilis, D.; Pakutinskas, P.; Malinauskaitè, I. 2016. Preconditions of sustainable ecosystem: cyber security policy and strategies, Entrepreneurship and Sustainability Issues 4(2): 174-182. https://doi.org/10.9770/jesi.2016.4.2(5)

Teivāns-Treinovskis, J.; Jefimovs, N. 2012. State national security: aspect of recorded crime, Journal of Security and Sustainability Issues 2(2): 41-48. http://dx.doi.org/10.9770/jssi.2012.2.2(4)

Tumalavičius, V. 2016. Security of Society in Lithuania: Concept and Scientific Fundamentals in its Ensuring. Sociālo Zinātņu Vēstnesis. 1(22): 92-118 pp. Daugavpils Universitāte, Humanitāro un sociālo zinātņu institūts. ISSN 1691-1881.

Tumalavičius, V.; Greičius, S. 2017. Decision Making of the Ensuring Public Security at the Level of the State Territorial Borders, Journal of Security and Sustainability Issues, 7(1): 27-37. http://dx.doi.org/10.9770/jssi.2017.7.1(3)

Tumalavičius, V.; Ivančiks, J.; Karpishchenko, O. 2016. Issues of Society Security: Public Safety under Globalisation Conditions in Lithuania, Journal of Security and Sustainability Issues 5(4): 545-570. http://dx.doi.org/10.9770/jssi.2016.5.4(9)

Tumas, V.; Čigrin, V. Kelių eismo saugumo užtikrinimo ypatumai [Peculiarities of Ensuring Road Traffic Safety]. Public security and public order. $2010,4$.

Tvaronavičienè, M. 2016. Start-ups across the EU: if particular tendencies could be trace, Entrepreneurship and Sustainability Issues 3(3): 290-298. http://dx.doi.org/10.9770/jesi.2016.3.3(6)

Zahars, V.; Stivrenieks, M. 2015. Security implementation facets: peculiarities of execution of the sentence of imprisonment in respect of convicted minors, Journal of Security and Sustainability Issues 4(3): 221-231. http://dx.doi.org/10.9770/jssi.2015.4.3(3)

\section{About contributors:}

Dr. Vladas TUMALAVIČIUS is a Lecturer of the Department of Management at The General Jonas Žemaitis Military Academy of Lithuania. Research interests: legal reguliation of public servants activity; legal regulation of public safety; legal issues of national, state and regional security.

Dr. Alvydas ŠAKOČIUS is the Professor of the Department of Management at The General Jonas Žemaitis Military Academy of Lithuania and Mykolas Romeris University. Research interests: public security, issues of state, regional security and sustainability. 